\title{
Grain Yield and its Components of Rice Cultivar Sakha 106 as Affected by Sowing Date, Hill Spacing and Zinc Fertilizer Level
}

\author{
Khairallah A. Sh. Shebl ${ }^{1}$, Ali I. Nawar ${ }^{1}$, Hossam Eldin M. Ibrahim ${ }^{1}$ and \\ Abd El-Salam A. Abd El- Salam ${ }^{2}$
}

\begin{abstract}
Two field experiments were conducted in the summer seasons of 2018 and 2019 at the Agricultural Research Station, Alexandria University, Egypt. The aim of the study was to investigate the effects of sowing date (May10, May 20, June 10 and June 20), hill spacing ( $10 \mathrm{x}$ 15, $15 \mathrm{x}$ $15,25 \times 15$ and $30 \times 15 \mathrm{~cm}$ ) and zinc sulphate fertilizer level ( $0,12,36$ and $48 \mathrm{~kg} \mathrm{ZnSO4/ha)} \mathrm{on} \mathrm{grain} \mathrm{yield} \mathrm{and}$ yield components of rice cultivar Sakha 106. The design applied in the two seasons was partially replicated central composite design in which factorial and star points were replicated three times.

The results indicated that delaying sowing resulted in progressive decrease in 100- grain weight and grain yield (beyond May 10), number of effective tillers $/ \mathrm{m}^{2}$ and number of grains/panicle (beyond May 30). Hill spacing of $20 \times 15 \mathrm{~cm}$ was found to be optimal for number of grains/panicle, 100- grain weight and grain yield/ha, whereas number of tillers/ $\mathrm{m}^{2}$ was highest at $30 \times 15 \mathrm{~cm}$ hill spacing. Zinc sulphate fertilization level of $48 \mathrm{~kg} / \mathrm{ha}$ increased all yield and yield components. It could be concluded to sow cultivar Sakha 106 in the region early on May 10 at hill spacing of $20 \times 15 \mathrm{~cm}$ and application of 48 $\mathrm{kg} \mathrm{ZnSO}_{4} / \mathrm{ha}$ to obtain high grain yield potential as a result of optimal production of yield components.
\end{abstract}

Key words: Rice, sowing date, hill spacing, zinc fertilizer, grain yield.

\section{INTRODUCTION}

Rice (Oryza sativa L.) is considered as one of the most important cereal crops not only in Egypt but also all over the world, and the second largest cultivated crop area after wheat. The total cultivated area with rice in Egypt was about 0.55 million hectare in 2019. Improvement of rice production can be achieved through different agronomic practices and treatments. Sowing date, hill spacing and zinc levels are amongst the agricultural practices that affect rice growth and productivity.

Sowing date of rice crop is important because it ensures that vegetative growth occurs during a period of satisfactory temperature and high levels of solar radiation and guarantees that grain filling occurs at suitable temperatures, hence good grain quality is achieved. (Bashir et al, 2010). Early sowing of rice tends to increase grain yield (Sha and Linscombe, 2007; Pal et al., 2017) through increasing number of effective tillers/plant (Safdar et al., 2008; Mrudulha and Rao, 2020) and number of grains per panicle (Safdar et al., 2008).

Hill spacing ensures appropriate distribution of plants in the field and supply of growth requirements at a suitable level. Optimum plant spacing ensures plants to grow properly both in their above and underground parts through different utilization of solar radiation and nutrients. Increasing plant density, through decreasing hill spacing or increasing number of plants per hill, led to increase grain yield of rice (Salem 2006; Vijayalaxmi et al.,2016) by increasing number of effective tillers $/ \mathrm{m} 2$ (Rex Immanuel et al., 2020). However, wider spacing increased number of grains/ panicle due to increase in fertility percentage and increase in grain weight (Anwari et al., 2019).

Zinc is an essential micronutrient for rice growth and productivity under submerged condition (Alam and Kumar, 2015). The role of zinc in photosynthesis and starch formation has been reported by Brown et al., (1993) and Marschner (1995). Also, zinc plays an important role in attaining membrane integrity (Welch et al., 1982). Proper fertilization management of submerged rice include the application of zinc for its enhancement of plant growth and productivity. Several researchers reported that application of adequate zinc levels increased rice grain yield (Sudha and Stalin, 2015; Ammanullah et al., 2020; Dhakad et al., 2020) through increasing yield components such as number of fertile tillers/m2 (Mafi et al., 2013) or number of grains/panicle (Mafi et al., 2013; Esfahani et al., 2014).

The main objective of the present study was to investigate the effect of sowing date, hill spacing and zinc levels on growth and productivity of Sakha 106 rice cultivar. 


\section{MATERIAL AND METHODS}

The present investigation was carried out at the Agricultural Research Station, Alexandria University, during the two summer seasons of 2018 and 2019. The objective of this study was to determine the effect of sowing date, hill spacing and zinc application levels on yield and yield components of rice cultivar Sakha 106.

Sakha 106 is a japonica type cultivar developed in 2010 by crossing of Giza 177 Egyptian early variety as female parent and Hexi 30 early Korean variety as male parent. Duration of Sakha 106 is around 126 days from seed to seed. It is a short grain type with low amylose content and high milling out turn (Kandil et al. 2012). The nursery seedbed and permanent field were prepared by mechanical plowing, harrowing and leveling. Grains were soaked in water for two days, followed by an incubation period of 2-3 days for seed germination initiation. The permanent field experimental size unit was $2 \times 2=4 \mathrm{~m}^{2}$.
Super phosphate (15.5\% P2O5), at the rate of 250 $\mathrm{kg} / \mathrm{ha}$, was incorporated into the soil of nursery seedbed and permanent field during land preparation in both seasons . Nitrogen, in the form of urea $(46 \%)$, was applied at the rate of $150 \mathrm{~kg} / \mathrm{ha}$, after 5 and 25 days from transplanting in the two seasons. Meanwhile, a dose of $17 \mathrm{~kg} \mathrm{~N} / \mathrm{ha}$ was applied in the nursery.

The plots were continuously kept flooded with irrigation water throughout the growing season. Weeds were chemically controlled using SHNEL 50\% applied 4-7 days after transplanting. In some cases, weeds were manually controlled in nursery and permanent field.

A partially replicated central composite design (Dykstra, 1960) of three replications was used in the two seasons of study. In that design, factorial and star points were replicated to obtain an estimate of error variance instead of central points as in the rotatable central composite design. The factors and levels of each factor are presented in the following table:

Table 1. Physical and chemical properties of soil of experimental site as an average of the two seasons

\section{Physical properties chemical properties $\operatorname{Cations}\left(\operatorname{meqL} L^{-1}\right) \quad \operatorname{Anions}\left(\operatorname{meqL}^{-1}\right)$}

\begin{tabular}{|c|c|c|c|c|c|c|c|c|}
\hline Sand $\%$ & 43.5 & \multicolumn{2}{|c|}{$\mathrm{EC}\left(\mathrm{dsm}^{-1}\right) 1.58$} & $\mathrm{Ca}^{++}$ & 3.87 & $\mathrm{CO}^{--}$ & 1.43 & 4.94 \\
\hline Silt $\%$ & 16.8 & $\mathrm{PH}$ & 8.44 & $\mathrm{Mg}^{++}$ & 3.81 & $\mathrm{HCO}^{-}$ & 3.56 & $\mathrm{CaCO} 3 \% 8.82$ \\
\hline Clay $\%$ & 39.5 & OM \% & 2.47 & $\mathrm{Na}^{+}$ & 9.66 & $\mathrm{Cl}^{-}$ & 6.33 & Available \\
\hline \multicolumn{4}{|c|}{ Sandy clay loam } & $\mathrm{K}^{+}$ & 0.68 & $\mathrm{SO}^{--}$ & 6.7 & Zn (ppm) 2.64 \\
\hline
\end{tabular}

Table 2. Average maximum, average and minimum temperatures at experimental site during 2018 and 2019 seasons

\begin{tabular}{lcccccc}
\hline \multicolumn{1}{r}{ Month } & \multicolumn{3}{c}{ Season 2018 } & \multicolumn{3}{c}{ Season 2019 } \\
\hline \multirow{2}{*}{ April } & Max. & Ave. & Min. & Max. & Ave. & Min. \\
\cline { 2 - 7 } & 26.9 & 20.7 & 17.33 & 24.7 & 18.3 & 14.9 \\
May & 29.6 & 24.2 & 20.9 & 31.7 & 23.2 & 18.7 \\
June & 29.8 & 26.4 & 24.3 & 28.4 & 26.5 & 24.4 \\
July & 32.05 & 27.9 & 25.8 & 30.11 & 28.05 & 25.6 \\
August & 29.2 & 28.3 & 26.7 & 29 & 28.05 & 26.18 \\
September & 28.7 & 27.3 & 25.6 & 27.8 & 26.5 & 24.6 \\
\hline
\end{tabular}


A partially replicated central composite design (Dykstra, 1960) of three replications was used in the two seasons of study. In that design, factorial and star points were replicated to obtain an estimate of error variance instead of central points as in the rotatable central composite design. The factors and levels of each factor are presented in the following table:

\begin{tabular}{lcccccc}
\hline Levels & Coded & $\mathbf{- S}$ & $\mathbf{- F}$ & $\mathbf{0}$ & $\mathbf{+ F}$ & $\mathbf{+ S}$ \\
\hline Factors & & & & & & \\
Sowing date & & 10 & 20 & 30 & 10 & 20 \\
(SD) & & - & - & - & - & - \\
& 5 & 5 & 5 & 6 & 6 \\
Hill spacing & & 10 & 15 & 20 & 25 & 30 \\
$(\mathrm{~cm})(\mathrm{HS})$ & Actual & $\mathrm{X}$ & $\mathrm{X}$ & $\mathrm{X}$ & $\mathrm{X}$ & $\mathrm{X}$ \\
& & 15 & 15 & 15 & 15 & 15 \\
Zinc & & & & & & \\
level(ZnSO4 & 0 & 12 & 24 & 36 & 48 \\
$\mathrm{~kg} / \mathrm{ha})(\mathrm{Zn})$ & & & & & & \\
\hline
\end{tabular}

S (-), S (+): star points, lowest and highest levels from studied factors, respectively.

F (-), F (+): factorial points, lower and higher levels from studied factors, respectively.

0 : central levels from each factor.

Analyses of data were carried out according to Cochran and Cox (1957) using Statistica Ver. 7, Statssoft, 2012 and curves were obtained using Curve Expert.

The studied characters in that experiment included:

1-Grain yield (ton/ha): taken from the inner $3.0 \mathrm{~m}^{2}$ of each plot and converted to tons/ha.

2-Number of effective tillers $/ \mathrm{m}^{2}$ : taken from a random one-squared meter per plot in guarded rows.

3-Number of grains per panicle: average of three random panicles from each plot.

4- 100 - grain weight: average weight of three random samples, each of 100 random rice grains.

The meteorological data and analysis of data indicated the homogeneity of experimental conditions and error for the two seasons (Hartley, 1950), hence data of the experiment were averaged and analyzed. The year component and its interaction with applied factors was insignificant for all components, hence it was not included in the reported analysis of variance.

\section{RESULTS AND DISCUSSION}

\section{RESULTS}

Analysis of variance and regression analyses presented in table (3) revealed that number of effective tillers $/ \mathrm{m}^{2}$ was significantly and negatively affected by linear effect of sowing date, positively by linear effect of zinc level, and negatively by linear interactions of sowing date $\mathrm{x}$ hill spacing and sowing date $\mathrm{x}$ zinc levels. The model describing the relationship between the studied factors and number of effective tillers $/ \mathrm{m}^{2}$ is $\mathrm{Y}=\beta_{0}-\beta_{1} \mathrm{SD}+\beta_{3} \mathrm{Zn}-\beta_{12} \mathrm{SD}$ X HS $-\beta_{13} \mathrm{SD}$ X Zn, with $R^{2}$ value of $=0.93$.

With regard to number of grains per panicle, that character was significantly and negatively affected by linear and quadratic effects of sowing date, and positively and negatively affected by linear and quadratic effects of hill spacing, respectively while it was positively and negatively affected by linear and quadratic effects of zinc levels, respectively. In addition, the linear interaction SD $X$ HS was significant and negative. The model for that character is $Y=\beta_{0}-\beta_{1}$ SD $-\beta_{11} \mathrm{SD}^{2}+\beta_{2} \mathrm{HS}-\beta_{22} \mathrm{HS}^{2}+\beta_{3} \mathrm{Zn}-\beta_{33} \mathrm{Zn}^{2}-\beta_{12} \mathrm{SD}$ $\mathrm{X} \mathrm{HS}$, with $\mathrm{R}^{2}$ value of 0.88 .

On the other hand, 100- grain weight was significantly and negatively affected by linear effects of both sowing date and hill spacing, while it was positively affected by linear effect of zinc levels. In addition, the linear interaction HS X Zn was significant. The model describing the relationship between the studied factors and 100- grain weight is $Y=\beta_{0}-\beta_{1}$ SD $\beta_{2} \mathrm{HS}+\beta_{3} \mathrm{Zn}+\beta_{23} \mathrm{HS} X \mathrm{Zn}$, with $\mathrm{R}^{2}=0.69$.

Regarding grain yield / ha, the analysis showed a significant and negative linear effect for sowing date, significant and positive response for quadratic effects of sowing date and hill spacing, and both linear and quadratic effects of zinc levels. Hence, the model describing that character is $\mathrm{Y}=\beta_{0}-\beta_{1} \mathrm{SD}+\beta_{11} \mathrm{SD}^{2}+$ $\beta_{22} \mathrm{HS}^{2}+\beta_{3} \mathrm{Zn}+\beta_{33} \mathrm{ZN}^{2}$, with $\mathrm{R}^{2}=0.89$. 
Table 3. Analysis of variance and regression coefficients of effective tillers $/ \mathbf{m}^{2}$, number of grains/panicle, 100grain weight and grain yield

\begin{tabular}{|c|c|c|c|c|c|c|c|c|}
\hline \multirow[t]{2}{*}{ Factors } & \multicolumn{2}{|c|}{$\begin{array}{c}\text { No. of effective } \\
\text { tillers } / \mathrm{m}^{2}\end{array}$} & \multicolumn{2}{|c|}{$\begin{array}{c}\text { No. of grains per } \\
\text { panicle }\end{array}$} & \multicolumn{2}{|c|}{ 100-grain weight } & \multicolumn{2}{|c|}{ Grain yield } \\
\hline & MS & $\mathbf{b}$ & MS & $\mathbf{b}$ & MS & b & MS & b \\
\hline Intercept & 301.9* & - & $191.8 *$ & - & 3.8* & - & $4.5^{*}$ & - \\
\hline SD L & $13763.5^{*}$ & $-57.9 *$ & $1082.4 *$ & $-5.14 *$ & $0.22 *$ & $-0.074 *$ & $8.30^{*}$ & $-0.45^{*}$ \\
\hline SD Q & 1149.9 & 61.75 & $280.9^{*}$ & $-30.5^{*}$ & 0.024 & -0.28 & $0.32 *$ & $1.03 *$ \\
\hline HS L & 936.7 & 4.7 & $57.8^{*}$ & $1.18^{*}$ & $0.029 *$ & $-0.026^{*}$ & 0.14 & 0.05 \\
\hline HS Q & 478.4 & 39.8 & $268.4^{*}$ & $-29.8 *$ & 0.018 & -0.24 & $0.27 *$ & $0.95 *$ \\
\hline $\mathrm{ZN} \mathrm{L}$ & $3744.1 *$ & $30.2 *$ & $177.8^{*}$ & $2.07 *$ & $0.037 *$ & $0.030 *$ & $4.21 *$ & $0.32 *$ \\
\hline ZN Q & 1341.6 & 66.7 & $271.2 *$ & $-29.9 *$ & 0.026 & -0.29 & $0.44^{*}$ & $1.21 *$ \\
\hline SD L X HS & & & & & & & & \\
\hline $\begin{array}{c}\mathrm{L} \\
\text { SD L X ZN }\end{array}$ & $2926.0^{*}$ & $-11.0 *$ & $48.1^{*}$ & $-1.4^{*}$ & 0.006 & -0.016 & 0.081 & -0.05 \\
\hline $\begin{array}{c}\mathrm{L} \\
\mathrm{HS} \text { L X ZN }\end{array}$ & $2667.0^{*}$ & $-10.5^{*}$ & 0.66 & -.16 & 0.0016 & -0.008 & 0.081 & -0.05 \\
\hline $\mathrm{L}$ & 651.04 & -5.2 & 4.16 & 0.41 & $0.026^{*}$ & $0.033^{*}$ & 0.026 & -0.03 \\
\hline Error & \multicolumn{2}{|c|}{515.9} & \multicolumn{2}{|c|}{6.96} & \multicolumn{2}{|c|}{0.0063} & \multicolumn{2}{|c|}{0.06473} \\
\hline $\mathrm{R}^{2}$ & \multicolumn{2}{|c|}{0.93} & \multicolumn{2}{|c|}{0.88} & \multicolumn{2}{|c|}{0.69} & \multicolumn{2}{|c|}{0.89} \\
\hline
\end{tabular}

Data presented in Fig. (1-a) indicated the negative relationship between sowing date and number of effective of tillers $/ \mathrm{m}^{2}$, where a delay of one day in sowing would decrease number of effective tillers by about 4.76 tillers $\left(r^{2}=0.96\right)$. Means presented in table (4) indicated that the earliest sowing date, 10 May (S ()), gave significantly higher number of effective tillers $/ \mathrm{m}^{2}(564)$ compared to the latest sowing date, 20 June (S (+)) (389 tiller/ $\mathrm{m}^{2}$ ). On the other hand, Fig. (1b) revealed the positive relationship between that character and applied zinc levels, where every increase by $1 \mathrm{~kg}$ of $\mathrm{Zn}$ would increase that character by 3.16 tillers $\left(r^{2}=0.88\right)$. Means in table (4) indicated that the wider hill spacing (30 x 15) (S (+)) gave higher number of effective tillers (417) compared to narrow hill spacing $(10 \times 15)(S(-))(412)$. The effect of the interaction between sowing date and hill spacing for number of tillers $/ \mathrm{m}^{2}$ (fig. 1-c), indicated that the highest number of effective tillers was obtained in early sowing (10- 20 May) and wider hill spacing ( $25 \times 15,30 \times 15)$. In addition, the increase in numbers of tillers/ $\mathrm{m}^{2}$ in early sowing was higher than that in delayed sowing dates at wider hill spacing. The same trend of results was obtained for sowing date $*$ zinc levels interaction (fig. 1-d).

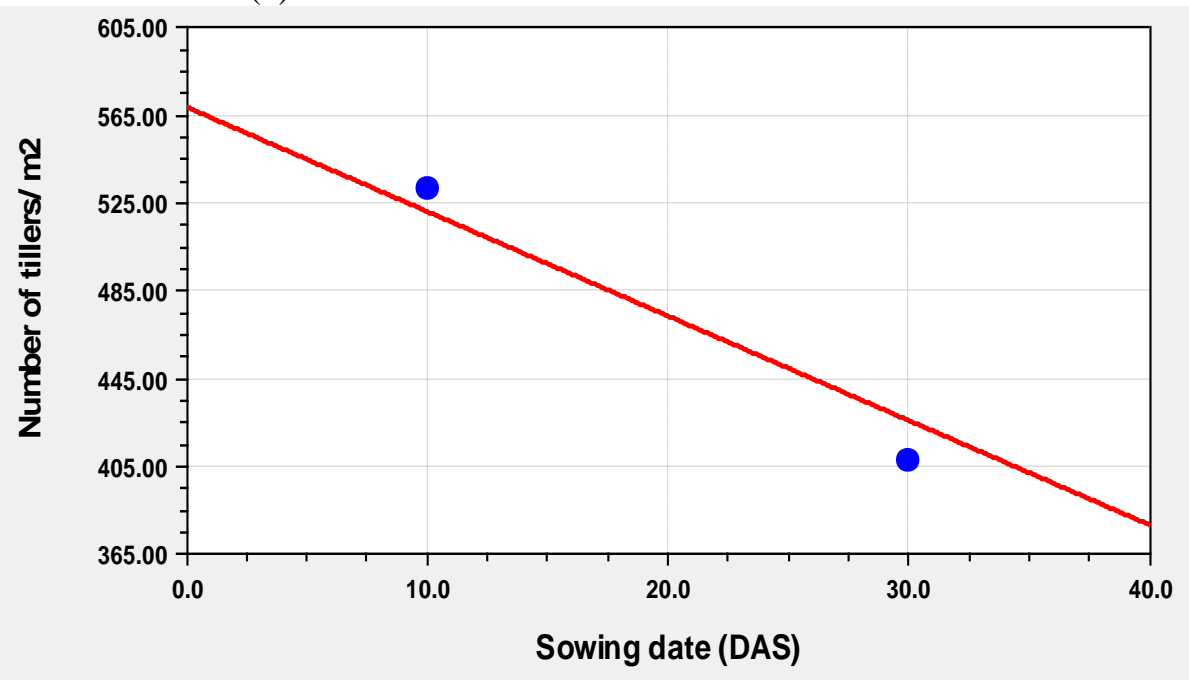

$\hat{\mathrm{Y}}=568.7-4.76 \mathrm{X}, \mathrm{r}^{2}=0.96$

Fig. 1-a. 


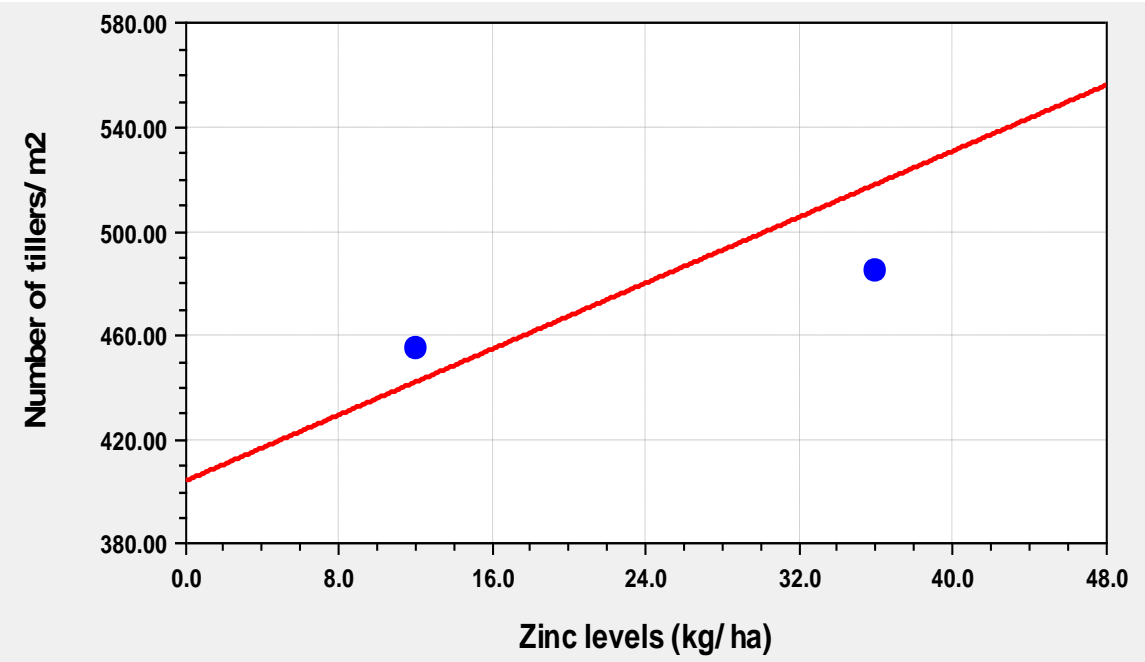

$\hat{\mathrm{Y}}=404.25+3.16 \mathrm{X}, \mathrm{r} 2=0.88$

Fig. 1-b.

Table 4. Means of yield and yield components characters as affected by applied treatments

\begin{tabular}{|c|c|c|c|c|c|c|c|c|}
\hline Points & $\begin{array}{c}\text { Sowing } \\
\text { date }\end{array}$ & $\begin{array}{c}\text { Factors } \\
\text { Hill } \\
\text { spacing } \\
\text { (cm) }\end{array}$ & $\begin{array}{c}\text { Zinc levels } \\
\text { (kg/ha) }\end{array}$ & $\begin{array}{c}\text { No. of } \\
\text { effective } \\
\text { tillers/m² }\end{array}$ & \multicolumn{2}{|r|}{$\begin{array}{c}\text { No.of } \\
\text { grain/panicle }\end{array}$} & $\begin{array}{l}\text { 100-grain } \\
\text { weight }(\mathrm{g})\end{array}$ & $\begin{array}{c}\text { Grain } \\
\text { yield } \\
(t / h .)\end{array}$ \\
\hline F1 & -1 & -1 & -1 & 480 & & 103.6 & 3.0 & 7.80 \\
\hline F2 & -1 & -1 & +1 & 548 & & 105.6 & 3.03 & 8.40 \\
\hline F3 & -1 & +1 & -1 & 533 & & 105.6 & 2.96 & 8.16 \\
\hline $\mathrm{F} 4$ & -1 & +1 & +1 & 567 & & 109 & 3.03 & 8.53 \\
\hline F5 & +1 & -1 & -1 & 406 & & 98 & 3.0 & 6.96 \\
\hline F6 & +1 & -1 & +1 & 419 & & 98 & 2.90 & 7.23 \\
\hline F7 & +1 & +1 & -1 & 402 & & 94 & 2.80 & 7.0 \\
\hline F8 & +1 & +1 & +1 & 406.6 & & 98 & 2.93 & 7.23 \\
\hline S1 & -1 & 0 & 0 & 564 & & 115.6 & 3.16 & 7.90 \\
\hline S2 & +1 & 0 & 0 & 389 & & 95.3 & 2.80 & 6.90 \\
\hline S3 & 0 & -1 & 0 & 412 & & 103.6 & 3.13 & 7.06 \\
\hline S4 & 0 & +1 & 0 & 417 & & 111.3 & 3.03 & 7.23 \\
\hline S5 & 0 & 0 & -1 & 403 & & 101.3 & 2.86 & 7.03 \\
\hline S6 & 0 & 0 & +1 & 578 & & 113 & 3.03 & 8.76 \\
\hline \multicolumn{4}{|c|}{ LSD } & 37.86 & & 4.97 & 0.118 & 0.42 \\
\hline \multicolumn{3}{|c|}{ Levels } & Coded & $-S$ & $-F$ & 0 & $+\mathrm{F}$ & $+\mathrm{S}$ \\
\hline \multicolumn{9}{|l|}{ Factors } \\
\hline \multicolumn{3}{|c|}{ Sowing date (A) } & Actual & $10-5$ & $20-5$ & $30-5$ & $10-6$ & $20-6$ \\
\hline \multicolumn{4}{|c|}{ Hill spacing $(\mathrm{cm})(\mathrm{B})$} & $10 \times 15$ & $15 \times 15$ & $20 \times 15$ & $25 \times 15$ & $30 \times 15$ \\
\hline \multicolumn{4}{|c|}{ Zinc level $(\mathrm{ZnSo} 4 \mathrm{~kg} / \mathrm{h})(\mathrm{C})$} & 0 & 12 & 24 & 36 & 48 \\
\hline
\end{tabular}




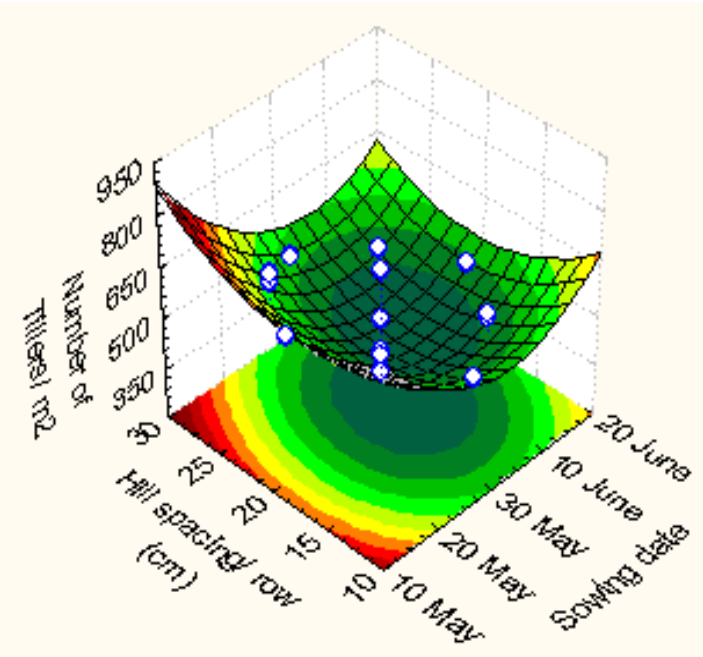

Fig. 1-c.

Data presented in Fig. (2-a) showed the negative relationship between sowing date and number of grains per panicle as affected by linear and quadratic effects where a delay of one day in sowing would decrease number of grains per panicle by 1.08 and 0.31 grains, $\left(r^{2}=0.83\right.$ and 0.90$)$, respectively. Means in table (4) indicated that early sowing on 10 May (S (-)) gave the highest number of grains/panicle (115.6) and that character decreased significantly with delaying sowing to 20 June (S (+)) (95.3).

Data presented in Fig. (2-b) indicated the negative relationship between number of grains per panicle and hill spacing as affected by linear and quadratic effects, where every increase of $1.0 \mathrm{~cm}$ in spacing would decrease that character by 0.32 and 2.87 grain, $\left(r^{2}=0.4\right.$ and 0.94), respectively. The data in table (4) also, revealed that wider hill spacing $(30 \times 15)(\mathrm{S}(+))$ gave the highest number of grains/panicle (111.3) compared to narrow hill spacing $(10 \times 15)(\mathrm{S} \mathrm{(-))} \mathrm{(103.6).}$

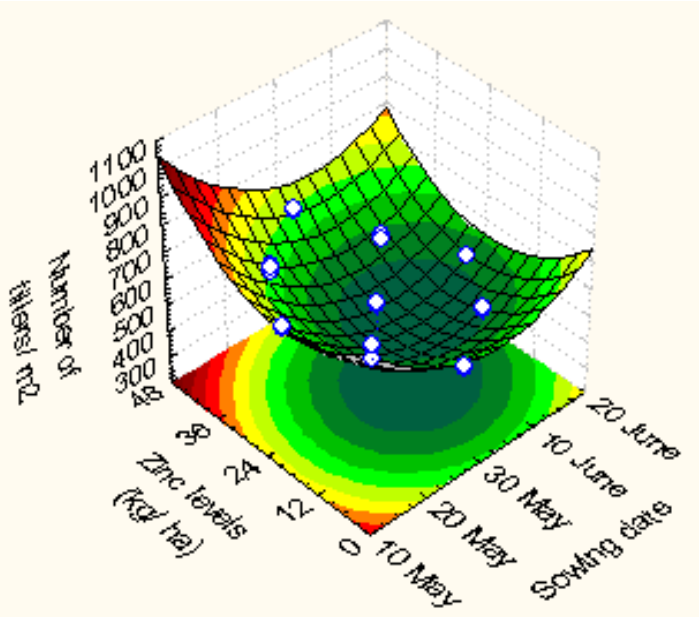

Fig. 1-d.

Data presented in Fig. (2-c) revealed the positive relationship between number of grains per panicle and applied zinc levels as affected by linear and quadratic effects, where every increase of $1 \mathrm{~kg}$ of $\mathrm{Zn}$ would increase that character by 0.21 and 0.40 grains $\left(r^{2}=0.64\right.$ and 0.94), respectively. On the other hand, data in table (4) showed that the application of highest level of zinc (48 $\mathrm{kg} \mathrm{ZnSO}_{4} / \mathrm{ha}$ ) (S (+)) gave significantly the highest number of grains (113) compared to no zinc (S (-)) application (101.3). The effect of the interaction between sowing date and hill spacing for number of grains/ panicle (fig. 2-d), indicated that the highest number of grains/panicle was obtained in early sowing (10- 20 May) and wider hill spacing $(30 \times 15 \mathrm{~cm})$.

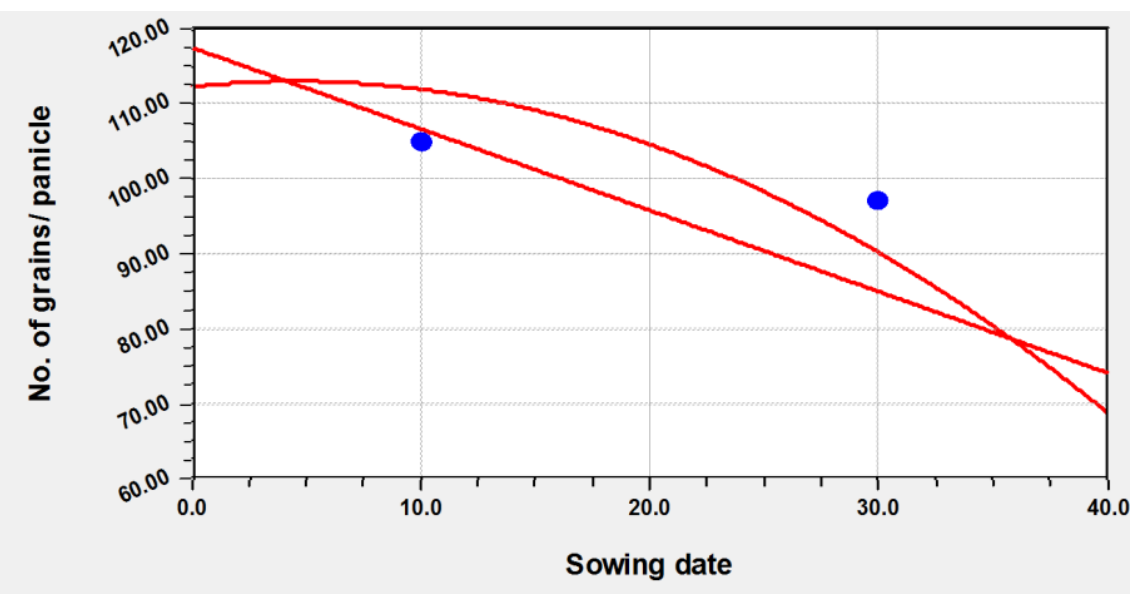

(L): $\hat{\mathrm{Y}}=117.48-1.08 \mathrm{X}\left(\mathrm{r}^{2}=0.83\right)$

Fig. 2-a.

(Q): $\hat{Y}=112.23+0.31 X-0.035 X^{2}\left(r^{2}=0.90\right)$ 


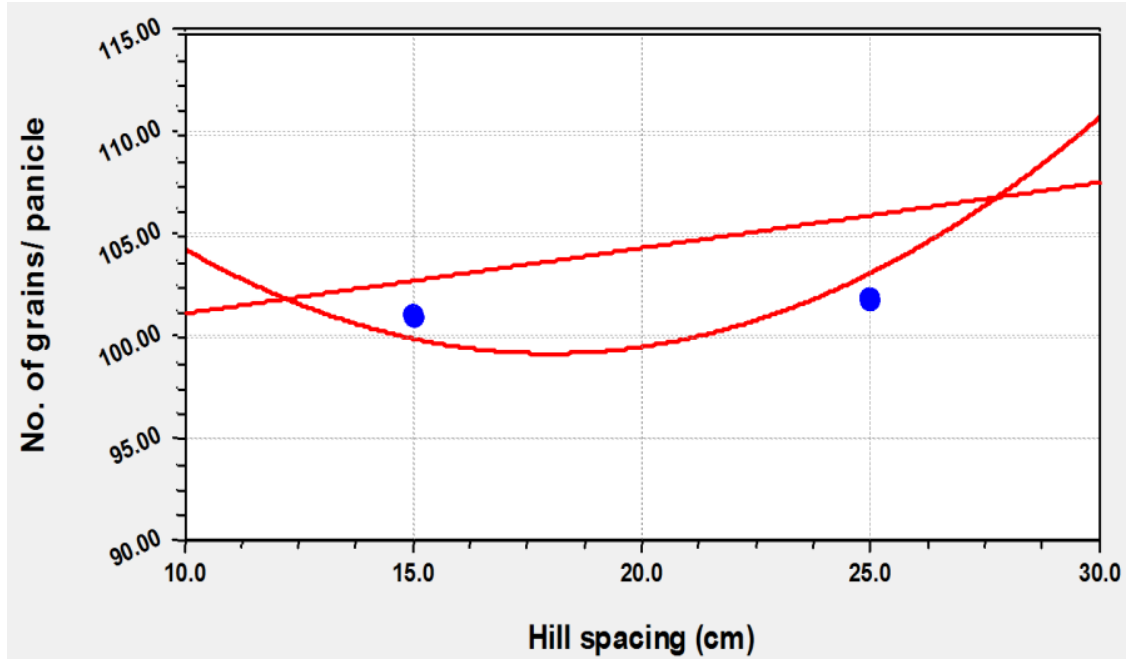

(L): $\hat{Y}=98.03+0.32 X\left(r^{2}=0.4\right)$

Fig. 2-b.

(Q): $\hat{Y}=125.06-2.87 \mathrm{X}+0.08 \mathrm{X}^{2}\left(\mathrm{r}^{2}=0.94\right)$

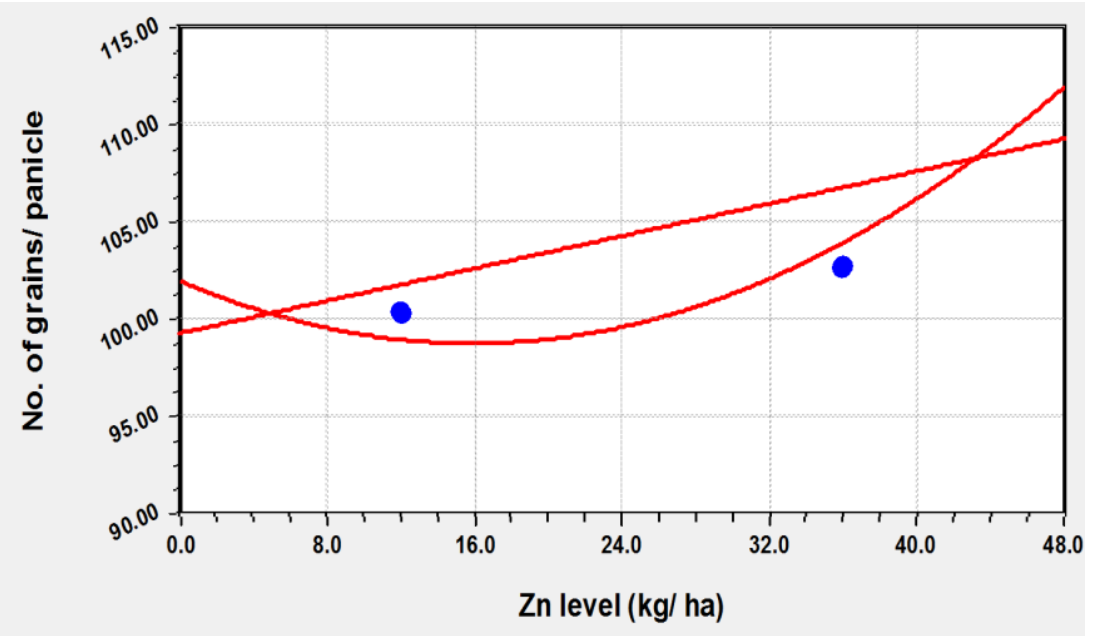

(L): $99.24+0.21 X(\mathrm{r} 2=0.64)$

Fig. 2-c.

$(\mathrm{Q}): \hat{\mathrm{Y}}=102-0.40 \mathrm{X}+0.013 \mathrm{X} 2(\mathrm{r} 2=0.94)$ 


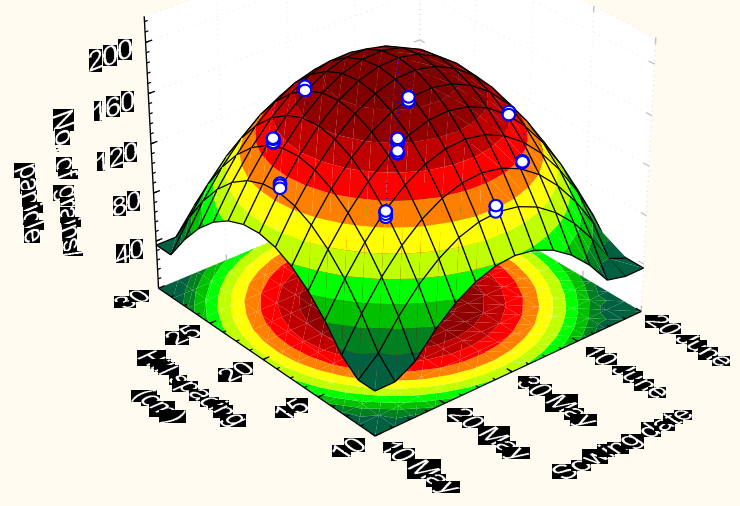

Fig. 2-d.

Data presented in Fig. (3-a) indicated the negative relationship between 100 - grain weight and sowing date where a delay of one day in sowing would decrease 100 - grain weight by about $0.008 \mathrm{~g}\left(\mathrm{r}^{2}=0.92\right)$. Means in table (4) indicated that early sowing on 10 May (S (-)) gave the heaviest 100 - grain weight $(3.16 \mathrm{~g})$ and that character decreased significantly with delaying sowing to 20 June $(\mathrm{S}(+))(2.80 \mathrm{~g})$. Data presented in Fig (3-b) indicated the negative relationship between that character and hill spacing where the increase of spacing would decrease 100- grain weight by about $0.005 \mathrm{~g}\left(\mathrm{r}^{2}=\right.$ 0.28 ). The data in table (4) also, revealed that wider hill spacing $(30 \times 15)(S(+))$ gave lower 100 - grain weight $(3.03 \mathrm{~g})$ compared to narrow hill spacing $(10 \mathrm{x} 15)$ (S ()) $(3.13 \mathrm{~g})$.

On the other hand, Fig. (3-c) revealed the positive relationship between 100- grain weight and applied zinc levels, where every increase by $1 \mathrm{~kg}$ of $\mathrm{Zn}$ would increase that character by $0.003 \mathrm{~g}\left(\mathrm{r}^{2}=0.90\right)$. The data in table (4) showed that application of highest level of zinc (48 $\mathrm{kg} \mathrm{ZnSO}$ /ha) (S (+)) gave significantly higher 100grain weight $(3.03 \mathrm{~g})$ compared to no zinc (S (-)) application $(2.86 \mathrm{~g})$. The effect of the interaction between zinc level and hill spacing for 100- grain weight (fig. 3-d), indicated that the heavier 100- grain weight was obtained with highest level of zinc (48 kg $\left.\mathrm{ZnSO}_{4} / \mathrm{ha}\right)$ and wider hill spacing $(30 \times 15 \mathrm{~cm})$.

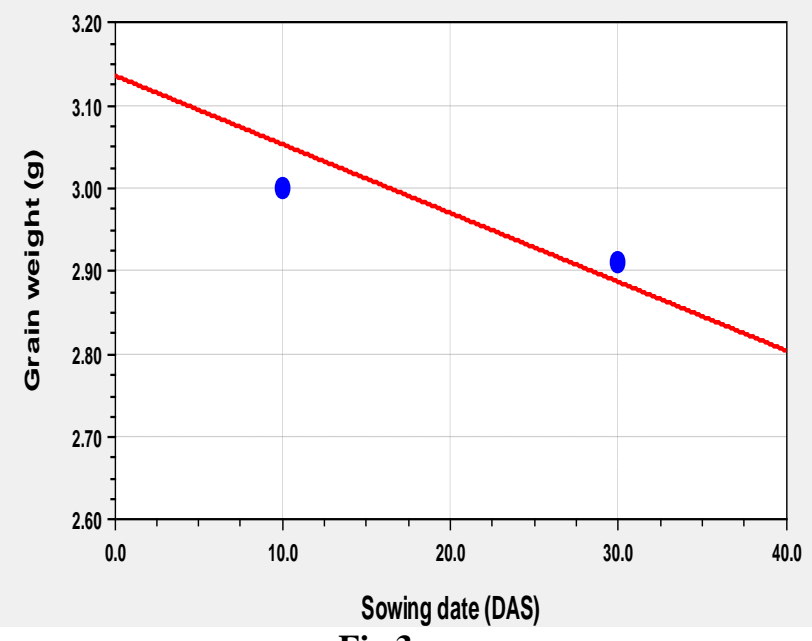

$\hat{\mathrm{Y}}=3.14-0.008 \mathrm{X}, \mathrm{r}^{2}=0.92$

Fig 3-a.

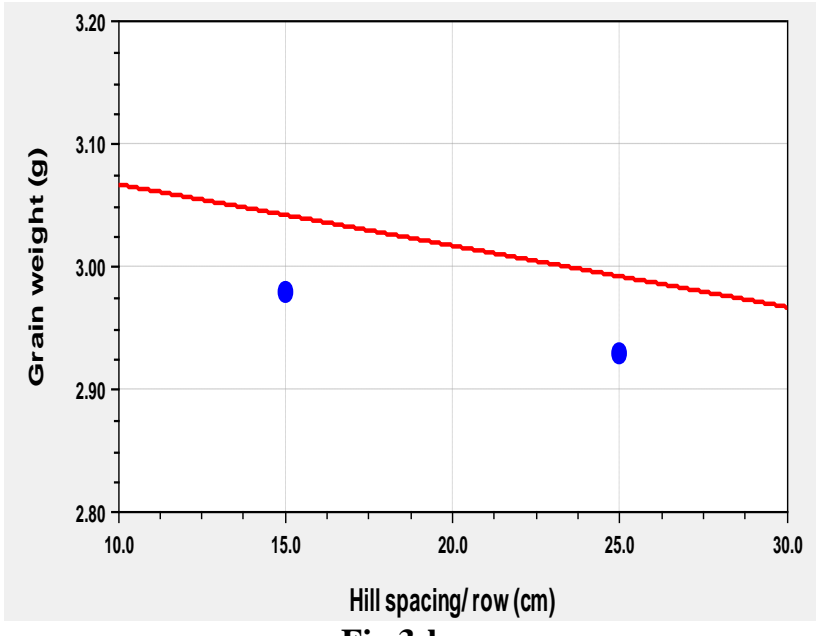

Fig 3-b.

$\hat{\mathrm{Y}}=3.11-0.005 \mathrm{X}, \mathrm{r}^{2}=0.28$ 


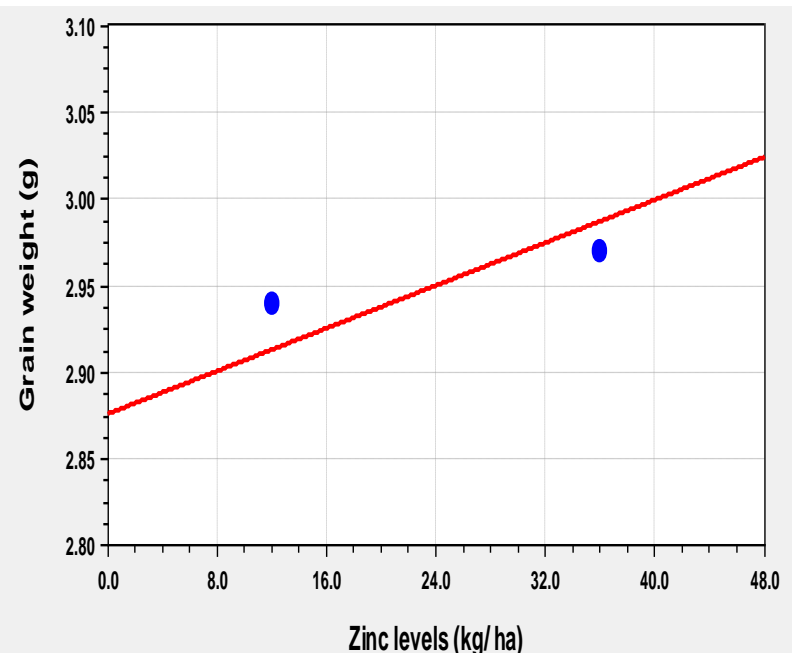

Fig 3-c.

$\hat{\mathrm{Y}}=2.87+0.003 \mathrm{X}, \mathrm{r}^{2}=0.90$

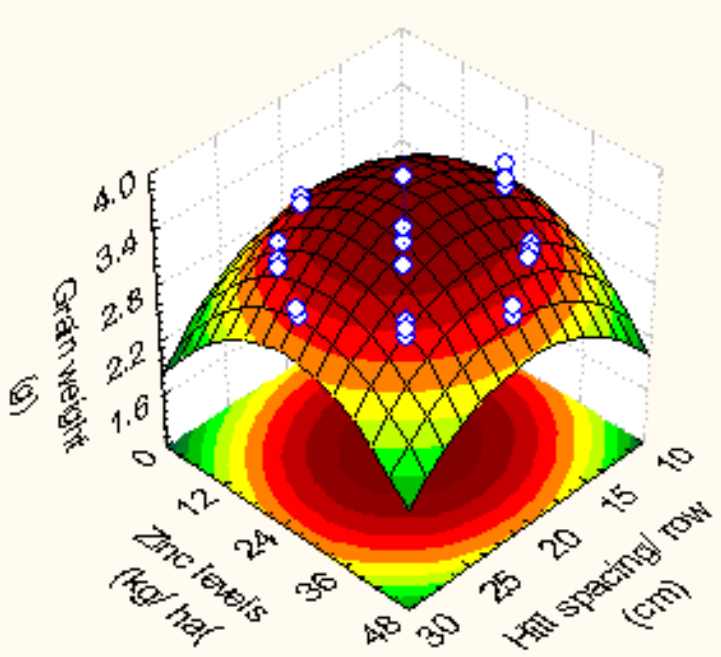

Fig 3-d.

Data presented in Fig. (4-a) indicated the negative relationship between grain yield/ ha and sowing date as affected by linear and quadratic effects, where a delay of one day in sowing would decrease that character by 0.03 and $0.004 \mathrm{t} / \mathrm{ha},\left(\mathrm{r}^{2}=0.81\right.$ and 0.86$)$, respectively. Means in table (4) indicated that early sowing on 10 May (S (-)) gave high grain yield (7.90 t/ha) and that character decreased significantly with delaying sowing to 20 June $(\mathrm{S}(+))(6.90 \mathrm{t} / \mathrm{ha})$.

Data presented in Fig. (4-b) revealed the positive relationship between grain yield/ ha and hill spacing up to $23 \times 15$ then gradually decreased as hill spacing was increased $\left(r^{2}=0.98\right)$. The data in table (4) also, revealed that wider hill spacing $(30 \times 15)(S(+))$ gave higher grain yield $(7.23 \mathrm{t} / \mathrm{ha})$ compared to narrow hill spacing $(10 \times 15)(7.06 \mathrm{t} / \mathrm{ha})$.
Data presented in Fig. (4-c) showed the positive relationship between grain yield/ ha and applied zinc levels as affected by linear and quadratic effects, $(\mathrm{r} 2=$ 0.90 and 0.92 , respectively). The data in table (4) indicated that the application of highest level of zinc ( $48 \mathrm{~kg} \mathrm{ZnSO} 4 / \mathrm{ha})(\mathrm{S}(+))$ gave significantly higher grain yield (8.76 t/ha) compared to no zinc (S(-)) application (7.03 t/ha).

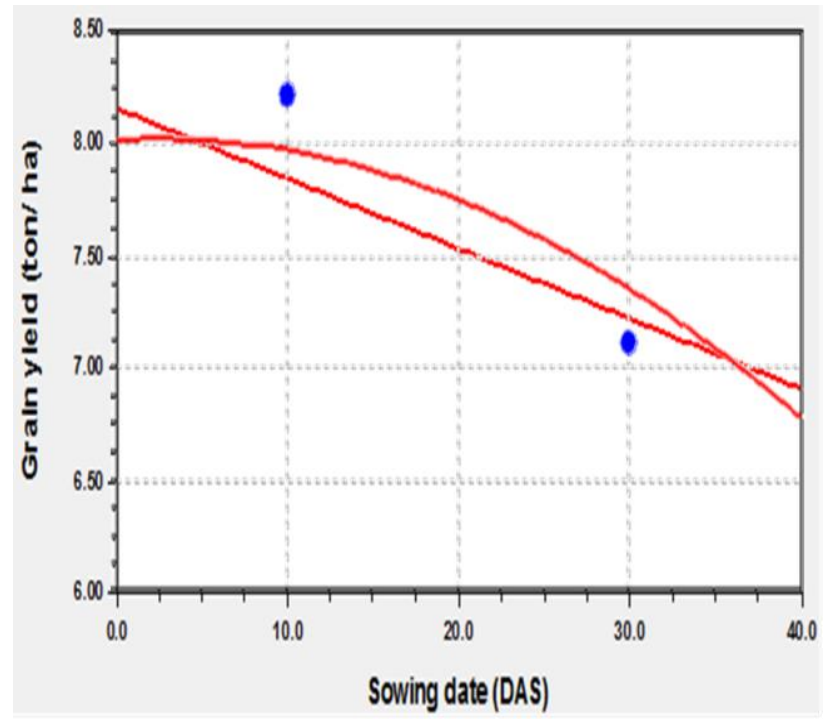

Fig. 4-a.

$\mathrm{L}: \hat{\mathrm{Y}}=8.15-0.03 \mathrm{X}, \mathrm{r}^{2}=0.81$

Q: $\hat{Y}=8.02+0.004 X-0.0008 X^{2}, r^{2}=0.86$

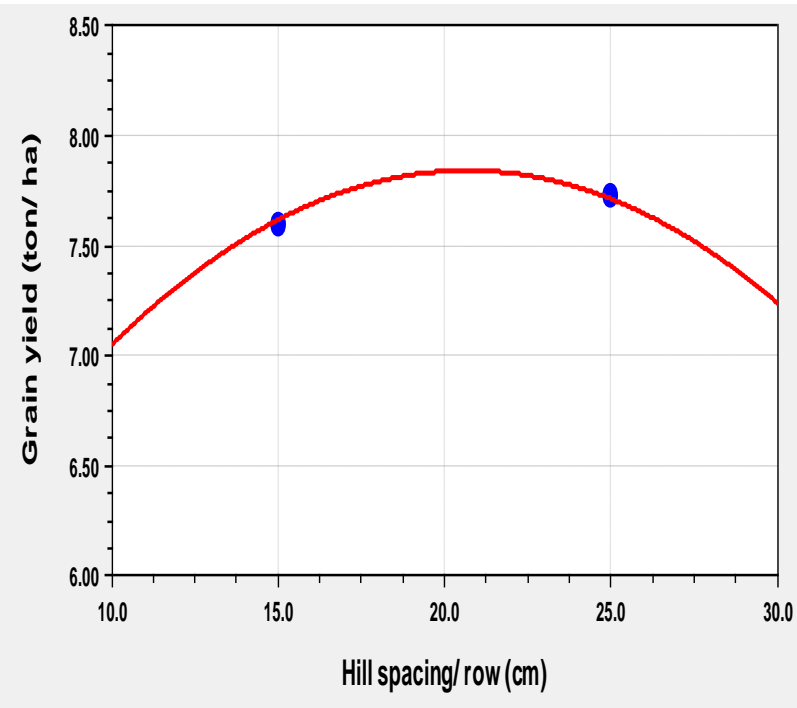

Fig. 4-b.

$\hat{\mathrm{Y}}=4.87+0.28 \mathrm{X}-0.006 \mathrm{X} 2, \mathrm{r} 2=0.98$ 


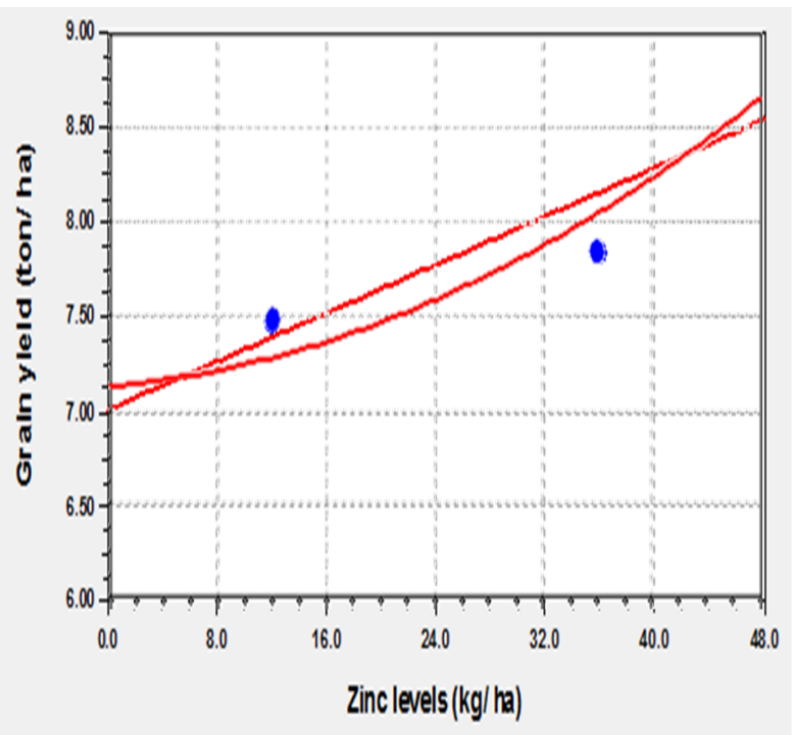

Fig. 4-c.

$\mathrm{L}: \hat{\mathrm{Y}}=7.01+0.03 \mathrm{X}, \mathrm{r} 2=0.90$

Q: $\hat{Y}=7.12+0.006 X+0.0005 X 2, r 2=0.92$.

\section{DISCUSSION}

The present investigation was carried out to study the effect of three factors, i.e.; sowing date, hill spacing and zinc application level, and their interactions on yield and yield components of rice cultivar Sakha 106. The factorial points for each factor were: sowing date (20 May and 10 June), hill spacing ( $15 \times 15 \mathrm{~cm}$ and $25 \mathrm{x}$ $15 \mathrm{~cm})$ and zinc fertilizer levels (12 and $36 \mathrm{~kg}$ $\left.\mathrm{ZnSO}_{4} / \mathrm{ha}\right)$. Application of the partially replicated central composite design added two more levels (star points) for each factor, viz. 10 May and 20 June for sowing date, $10 \times 15$ and $30 \times 15 \mathrm{~cm}$ for hill spacing and 0 and $48 \mathrm{~kg} \mathrm{Zn} \mathrm{SO}_{4} /$ ha for Zinc fertilizer levels.

Data revealed that number of effective tillers decreased linearly with delaying sowing up to 20 June (Fig 1-a). That may be attributed to the incidence of high temperatures in delayed sowing causing the plants to switch rapidly to the reproductive stage thus decreasing the tillering capacity of the rice plant and the number of grain-bearing tillers. Similar findings were reported by Safdar et al. (2008) and Mrudhula and Rao (2020). Increasing the application of zinc fertilizer linearly increased number of effective tillers $/ \mathrm{m}^{2}$ (Fig 1b). It has been reported that zinc plays an important role in rice tillering (Alloway, 2008) and fertility of spikelets (Fageria, 2009) for its role in pollen grain formation and viability. Amanuallah et al. (2020) found that increasing zinc levels led to increase number of fertile tillers $/ \mathrm{m}^{2}$. The interaction between sowing date and hill spacing (Fig 1-c) further showed that the highest number of effective tillers $/ \mathrm{m}^{2}$ was obtained at the earliest sowing date (10 May) and widest hill spacing (30 x 15),however decreasing hill spacing causes a decrease in that character. That may by be due to a direct effect for higher competition between plants, in high plant density, for ground space, leading to increasing vegetative growth and decreasing the production of tillers.

This is in agreement with the results reported by Anwari et al. (2019) and Rex Immanuel et al. (2020).

The same trend was observed for sowing date $\mathrm{x}$ zinc fertilization level interaction, where early sowing and higher applied zinc levels increased number of effective tillers $/ \mathrm{m}^{2}$. Similar findings were reported by Sudha and Stalin (2015) and Dhakad et al. (2020) who reported that increasing zinc application levels increased fertility and number of tillers/ $\mathrm{m}^{2}$.

Regarding number of grains/panicle, delaying sowing date (Fig 2-a) linearly and quadratically decreased that character, and that may be due to the coincidence of grain setting and filling stage of rice plant with adverse environmental conditions, i.e. high temperature, that affects pollen viability and the process of fertilization. Safdar et al. (2008) and Shabana et al. (2016) found the delayed sowing of rice led to a considerable decrease in number of grains/panicle. On the other hand, number of grains/panicle was increased with wider hill spacing (Fig 2-b). The linear relationship between number of grains/panicle and hill spacing was not conclusive $\left(r^{2}=0.4\right)$ whereas the quadratic relationship $\left(r^{2}=0.94\right)$ revealed that at narrower hill spacing, that character was decreased up to $20 \times 15$, then tended to increase with increasing hill spacing up to $30 \times 15 \mathrm{~cm}$. Wider hill spacings decreases intracompetition between rice plants for growth resources, hence rice plants are nutritionally balanced. In addition, wider spacings allow for more light penetration into the canopy and thus increases photosynthesis and photosynthates production which beneficially affects fertility percentage in the panicle and increases grain setting. Similar findings were reported by Pokharel $e t$ al. (2018) and Anwari et al. (2019). Application of zinc sulphate levels followed the same trend of hill spacing (Fig 2-c), where applied levels above $20 \mathrm{~kg} \mathrm{ZnSO} / /$ ha showed a gradual and substantial increase in number of grains /panicle up to $48 \mathrm{~kg} \mathrm{ZnSO}_{4} / \mathrm{ha}$. As reported by Alloway (2004) and Fageria (2009), zinc plays a major role in chlorophyll production and photosynthesis, metabolism of starch, pollen grain viability and grain setting. All that will affect number of grains/panicle, and hence, zinc deficiency will cause a reduction in that character (Alam and Kumar, 2015 and Mahmudi et al., 2015). The sowing date $x$ hill spacing interaction (Fig 2d) revealed that the highest number of grains/panicle resulted from sowing on May 30 and hill spacing of 20 $\mathrm{x} 15 \mathrm{~cm}$. Increasing the level of either factors, delayed 
sowing and narrower hill spacings, will decrease that character.

With regard to 100-grain weight (HGW), data revealed that this character followed the same trend as number of grains/panicle for sowing date (Fig 3-a) and zinc fertilizer level (Fig 3-c). HGW decreased with delaying sowing (Abou Khalifa and EL- Rewainy, 2012 and Abou Khalifa et al., 2014) and increased with increasing $\mathrm{ZnSO}_{4}$ levels (Ali et al. ,2014 and Mahmudi et al., 2015). On the other hand, a decrease in that character was observed with wider hill spacings above $20 \times 15 \mathrm{~cm}$ (Fig 3-b). That could be a result of increased number of grains/panicle which lead to a reduction in single grain weight. Similar findings were reported by Kandil et al. (2010) and Uddin et al. (2011) who found that increasing hill spacing beyond $20 \times 15 \mathrm{~cm}$ reduced grain weight.

The hill spacing $\mathrm{x}$ zinc level interaction (Fig 3-d) indicated that highest values for HGW resulted from sowing at $20 \times 15 \mathrm{~cm}$ hill spacing combined with application of $24 \mathrm{~kg} \mathrm{ZnSO} 4 / \mathrm{ha}$. Narrower hill spacings and higher zinc fertilizer levels reduced that character.

Grain yield showed a linear and negative relationship with sowing date (Fig 4-a). Delaying of sowing resulted in decreasing number of effective tillers $/ \mathrm{m} 2$, number of grains/panicle and 100- grain weight and that resulted in reduction of grain yield/ha. Similar results were reported by Pal et al. (2017) and Huang et al. (2020) who concluded that adverse environmental conditions (high temperature) affected panicle fertility levels and decreased grain weight, and consequently grain yield was reduced. With regard to the effect of hill spacing, the data (Fig 4-b) revealed a gradual increase in grain yield up to $20 \mathrm{x} 15 \mathrm{~cm}$ then gradually decreased at the widest hill spacing of $30 \times 15$ $\mathrm{cm}$. That may be interpreted by the compensation ability of rice plants to increase the number of effective tillers with the increase in hill spacing up to $20 \times 15 \mathrm{~cm}$. However, increasing the spacing to $30 \times 15 \mathrm{~cm}$ reduced grain yield as a result to the decrease in number of fertile tillers/ $\mathrm{m} 2$. Several researchers reported that $20 \mathrm{x}$ $15 \mathrm{~cm}$ gave higher yields than narrower or wider spacings (Aklilu et al. 2020 and Rex-Immanuel et al.,2020). Moreover, grain yield showed a linear and quadratic increase with increasing zinc fertilizer level (Fig 4-c). As reported by several investigators, zinc has beneficial effects on tillering (Alloway, 2008), fertility and grain formation (Fageria, 2009) and grain weight, through increasing photosynthesis and dry matter production (Abou Khalifa and EL-Rewainy,2012), and consequently increase grain yield. These findings were in agreement with those reported by Dhakad et al. (2020), and Huang et al. (2020).

\section{REFERENCES}

Abou Khalifa, A. A. A. and I. M. El-Rewainy.2012. Study some physiological characters, yield and yield components for five new rice varieties under different sowing dates. Advances in Applied Science Research, 3 (1):440-445.

Abou Khalifa, A. A., W. ELkhoby and E. M. Okasha. 2014. Effect of sowing dates and seed rates on some rice cultivars. African Journal of Agricultural research. 9(2) : 196-201.

Aklilu, E. 2020. Effect of Seed Rate and Row Spacing on Yield and Yield Components of Upland Rice (Oryza sativa L.) in Metema, West Gondar, Ethiopia. American Journal of Agriculture and Forestry, 8(4): 112-125.

Alam, M. D. A. and M. Kumar. 2015. Effect of zinc on growth and yield of rice var. Pusa Basmati-1 in Saran district of Bihar. Asian Journal of Plant Science and Research, 5(2): 82-85.

Ali, H. , Z. Hasnain, A.N. Shahzad, N. Sarwar, M.K. Qureshi, S. Khaliq and M.F. Qayyum .2014. Nitrogen and Zinc Interaction Improves Yield and Quality of Submerged Basmati Rice . Research Articles. Not. Bot. Hort. Agrobo. 42(2): 372- 379.

Alloway, B.J. 2004. Zinc In Soil and Crop Nutrition. Brussels Belgium: International Zinc Association.

Alloway, B.J. 2008. Zinc In Soil and Crop Production. $2^{\text {nd }}$ edition. Published by International Zinc Association and International Fertilizer Industry Association, Belgium and France.

Amanullah, I., Inamullah, J. Alkahtani, M. S. Elshikh, M. S. Alwahibi, M. Assim , Imran and S. Khalid .2020. Phosphorus and Zinc Fertilization Improve Productivity and Profitability of Rice Cultivars. Agronomy, 10,1085;doi:10.3390/agronomy 10081085.

Anwari, G., A. A. Moussa, A. B. Wahidi, A. Mandozai, J. Nasar and M. G. M. Abd el-Rahim .2019. Effects of planting distance on yield and agro- morphological characteristics of local rice (Bara Variety) in northeast afghanistan. Current Agriculture Research Journal. 7(3): 350-357.

Bashir, M. U., N. Akbar, A. Iqbal and H. Zaman. 2010. Effect of different sowing dates on yield and yield Components of direct seeded coarse rice (Oryza sativa L). Pak. J. Agri. Sci., 47(4) : 361-365.

Brown, P. H., I. Cakmak and Q. Zhang (1993) Form and Function of Zinc in Plants. In Robson, A. D. (ed.) Zinc in Soil and Plants, Kluwer Academic Publishers, Dordrech. Pp 90-106.

Cochran , W.G. and G. M. Cox. 1957. Experimental Design. $2^{\text {nd }}$ ed. Wiley, NY.

Dhakad, R., G.S. Tagore, B. Sharma, H.K. Rai, G.D. Sharma and S. Yadav .2020. Effect of zinc fertilization on growth, yield and micronutrients content and uptake by paddy. IJCS, 8(4): 2560-2564.

Dykstra, O. ,Jr. 1960. Partial Duplication of Response Surface Designs. Technometries, 2(2): 185- 195. 
El-Dalil, M. A.E., E. K.E. Abd-El Ghany, A. El-Ezz and A. Fouad. 2017. Yield, yield components and grain quality of Giza 179 Egyptian Rice Cultivar as affected by seeding rates and nitrogen levels using broadcasting planting method. Alexandria Science Exchange Journal, 38(4) : $707-715$.

Esfahani, A. A., H. Pirdashti and Y. Niknejhad. 2014. Effect of iron, zinc and silicon application on quantitative parameters of Rice (Oryza sativa L. CV.Tarom Mahalli). International Journal of Farming and Allied Sciences, 3(5) :529-533.

Fageria, N. K. 2009. The Use of Nutrients in Crop Plants. Pages: $241-271$.

Huang, M., S. Fang, F. Cao, J. Chen, S. Shan, Y. Liu, T. Lei, A. Tia , Z. Tao and Y. zou .2020. Early sowing increases grain yield of machine-transplanted late-season rice under single-seed sowing. Field Crops Research. doi.org/ 10.1016/J.Fcr.2020. 107832.

Kandil, A.A., A.E. , Sharief and E.S.E., Nassar. 2012. Response of some rice cultivars to germination under salinity stress. International Journal of Agriculture Sciences, 4(6): 272- 277.

Kandil, A. A., , S.E. El-Kalla, A.T. Badaw and O. M. ElShayb. 2010. Effect of hill spacing, nitrogen levels and harvest date on rice productivity and grain quality. Crop \& Environment, 1(1): 22-26.

Mafi, S., S. M. Sadeghi, and H. Doroodian. 2013. Effect of zinc and phosphorus fertilizers on yield and yield components of rice (Hashemi). Persian Gulf Crop Protection ,2 (2): 30-36.

Mahmudi, J., S. Sharafi, M. Tanha and R. Hassanzade. 2015. Effect of $\mathrm{Zn}$ and $\mathrm{K}$ elements on yield and yield components of rice (Oryza sativa L.) cv. Tarom Hashemi. International Journal of Farming and Applied Sciences, 4 (1): 1-5.

Marschner, H. 1995. Mineral Nutrition of Higher Plants. $\left(2^{\text {nd }}\right.$ ed. ) Academic Press, London. 889 pp.

Ministry of Agric., Agric. Res. Center, Field Crops Res. Institute. 2020.

Mrudhula, A., and C.,V., R., Rao. 2020. Effect of sowing window on growth parameters and yield of different rice varieties in Krishna western delta. Journal of Pharmacognosy and Phytochemistry, 9(4): 1081-1085.

Pal, R., G. Mahajan, V. Sardana and B. S. Chauhan. 2017. Impact of sowing date on yield, dry matter and nitrogen accumulation, and nitrogen translocation in dry-seeded rice in North-West India. Field Crops Research 206: 138148.
Pokharel, S., L.P. Amgain, B. Sapkota, A. Khanal and T.B. Gurung. 2018. Effect of spacing and number of seedling hill $^{-1}$ on grain yield and other agronomic traits of hybrid rice (U.S. 312) on late transplantation. Journal Material Science. DOI: 10.19080/JOJMS.2018.04.555652.

Radwan, F.I., M. A. Gomaa, E. E. Kandil and A. F. Gharib. 2015. Effect of nitrogenous sources and zinc application method on productivity and quality of rice (Oryza sativa L.). Middle East Journal of Applied Sciences, 5 (4) : 913919.

Rex Immanuel R., M. Thiruppathi, G.B. S. Rao and S. S. Gandhi. 2020. Plant spacing and integrated nitrogen management effects on yield and economics of direct spot seeded rice in Coastal Tamilnadu, India. Plant Archives, 20( 2) : 2715-2721.

Safdar, M.E., A. Ali, S. Muhammad, G. Sarwar and T. H. Awan. 2008. Effect of transplanting dates on paddy yield of fine grain rice genotypes. Pak. J. Bot., 40(6): 24032411.

Salem, A.K.M (2006). Effect of nitrogen levels, plant spacing and time of farmyard manure application on the productivity of rice. Journal of Applied Sciences Research, 2(11): 980-987.

Shabana, T., K.N. Singh, D. S. Hussain, S. T. Hussain and S. Parmeet. 2016. Effect of different transplanting dates on yield and yield components of rice (Oryza sativa L.) International Journal of Agriculture Sciences, 8(62): 90759107.

Sha, X. Y. and S. D. Linscombe. 2007. Planting date affects grain and milling yields of water- seeded clear field rice. Agronomy journal. 99: 1143-1150.

Sudha, S. and P. Stalin. 2015. Effect of zinc on yield, quality and grain zinc content of rice genotypes. International Journal of Farm Sciences, 5(3) :17- 27.

Uddin, M. J., S. Ahmed, M. H.Rashid, Md. M. Hasan and M. A. zaman. 2011. Effect of spacing on the yield and yield attributes of transplanted Aman rice cultivars in medium lowland ecosystem of Bangladesh. J. Agric. Res., 49(4) :465 - 476 .

Vijayalaxmi, G., G. Sreenivas, P. L. Rani and A. Madhavi. 2016. Effect of plant densities and age of seedling on growth and yield parameters of kharif rice. International Journal of Science, IEnvironment and Technology, 5 (3): 1153 - 1162 .

Welch, R.M., M.J. Webb, and J.F. Loneragan. 1982. Zinc in Membrane Function and Its Role in Phosphorus Toxicity (Crop). In Plant Nutrition. Proceedings of $9^{\text {th }}$ International plant Nutrition Colloquium, Warwick University, England, August 1982. Scaife, A.(ed.) pp 710-715. 


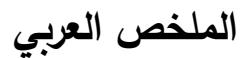

تأثير ميعاد الزراعة والمسافات بين الجور ومستوي التسميد بالزنك علي محصول الحبوب ومكوناته في

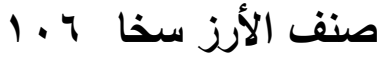

خيرالله عبدالنبي شفيق شبل، علي عيسي نوار ، حسام الدين محمد إبراهيم ، عبدالسلام عباس عبدالسلام

مايو) وعدد الخلفات الحاملة للسنابل وعدد الحبوب في النورة

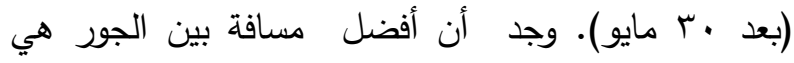

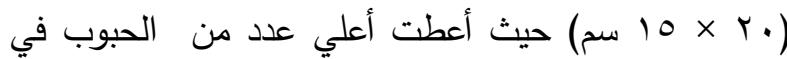

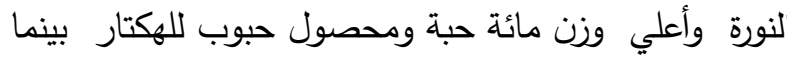

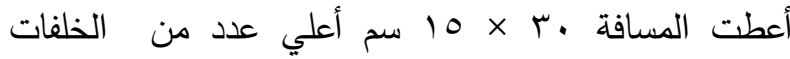

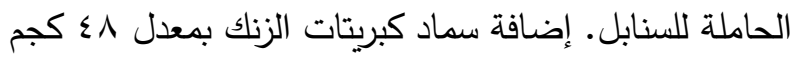

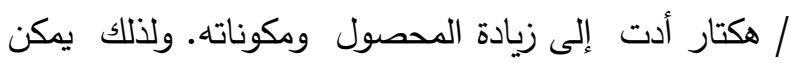

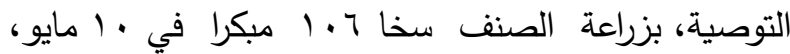

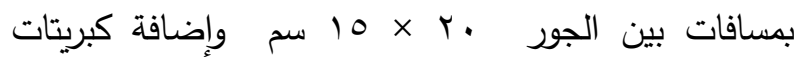

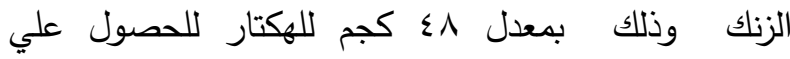
محصول حبوب عالي نتيجة للتحسين في مكونات

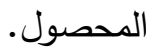

أجريت تجربتين حقليتين في الموسم الصيفي لعامي

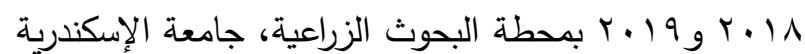

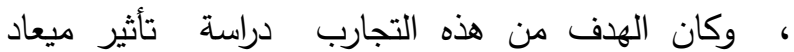

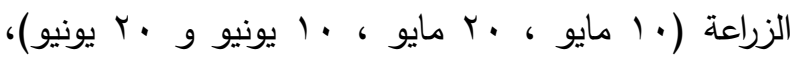

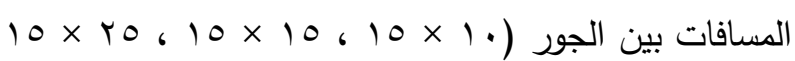

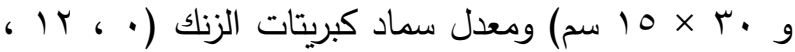

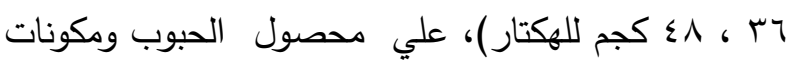
المحصول في صنف الأرز سخا ؟ ـ1. التصميم الإحصائي المستخدم في كلا الموسمين هو تصميم مركب مركزي مكرر ، حيث تم تكرار النقاط العاملية والمحورية ثلاث مرات. أوضحت النتائج أن التأخير في ميعاد الزراعة أدى الثى إلى نقص في وزن المائة حبة ، محصول الحبوب (بعد ل 